\title{
GRANÁTICKÉ PÁSKOVANÉ ANOROGENNÍ GRANITY A PEGMATITY SUITY HLÍNA V BRUNOVISTULIKU - TEXTURY A PLOŠNÉ ROZŠíŘENÍ
}

\author{
Garnet-bearing layered anorogenous granites and pegmatites of the Hlína Suite inside the \\ Brunovistulicum - structures and field occurrences
}

Sven Hönig, Jaromír Leichmann, Tomáš Novosád

Ústav geologických věd PřF MU, Kotlářská 2, 61137 Brno; e-mail: honig@mail.muni.cz

(24-34 Ivančice, 34-11 Znojmo, 34-12 Pohořelice, 34-13 Dyjákovice, 33-22 Vranov nad Dyjí, 33-24 Hnanice)

Key words: Brunovistulicum, Brno Batholith, Thaya Batholith, layering, layered granite

\begin{abstract}
The SW part of the Brno Batholith as well as NE part of the Thaya batholith have undergone recent mapping focused on layered granite dykes belong to the Hlina A-type granite suite. Dykes cropping out throughout the both other granitic suites in the region (Réna I-type and Tetčice S-type) widespread more than $60 \mathrm{~km}$ in N-S direction. Structures of the Hlina granites are easily distinguishable by their layering parallel to the contact, alternating of major aplite-like zones and minor pegmatite-like zones with oriented UST comb-like Qtz, Pl and Kfs. The lamination of the rock is pronounced by parallel stripe-like arrangement of the garnet. The purpose of text below is highlighted the volumetrically scarce but genetically very important part of the Brunovistulian unit.
\end{abstract}

\section{Úvod}

Během let 2007-2012 bylo navštíveno, zmapováno a znovu objeveno relativně velké množství výchozů páskovaných žilných granitů (s afinitou $\mathrm{k}$ A-typovým granitům) $\mathrm{v}$ oblasti ležící přibližně mezi Ivančicemi a řekou Dyjí. Tyto práce proběhly $\mathrm{v}$ rámci zpracovávání diplomových a bakalářských prací ÚGV PřF MU (Hönig 2008, Novosád 2011). Výchozy byly zaměřeny pomocí GPS (typ Garmin 60CSx). Pro jejich následné zpracování byl použit program ArcGIS 9.3 s prerekvizitami: CGS - J STK_Křovák, datum WGS 1984.

Brněnský a dyjský batolit reprezentují dvě nejlépe odkryté oblasti brunovistulika. Leichmann a Höck 2008) považují, podobně jako Finger et al (1995), severní část dyjského batolitu za př́mé pokračování západní granitoidní zóny brněnského batolitu. I-typové granity a granodiority suity Réna definované v brněnském batolitu paralelizují na základě petrologických a geochemických znaků s granity typu Pulkau/Zellendorf dyjského batolitu. Horniny suity Tetčice - diority, S-typové granity uzavírající enklávy rul z brněnského batolitu, mohou být opět na základě dat litologických a geochemických srovnávány s granity vycházejícími sv. od Znojma v batolitu dyjském. Dalším společným znakem tohoto litologického typu je pozitivní tíhová anomálie indikující pravděpodobné větší rozšírení dioritů a př́ibuzných hornin v hloubce. Detailní srovnání obou batolitů je možno nalézt v Leichmann a Höck (2008).

Horniny typu Hlína byly vymapovány především uvnitř I-typových amfibol-biotitických až biotitických granitů typu Réna a jejich ekvivalentu v dyjském batolitu - Pulkau/Zellendorf, avšak drobné výskyty se nepravidelně objevují i uvnitř S-typových biotitických granitů typu Tetčice v brněnském batolitu (obr. 1).

\section{Brněnský batolit}

Žilné granity typu Hlína vystupují v podobě drobných 0,5-50,0 m mocných a až $100 \mathrm{~m}$ dlouhých žil, žilných rojů nebo ojedinělých čoček. $V$ západní části brněnského batolitu je většina žil orietována sz.-jv. směrem. Kontakt s okolními granitoidy je většinou ostrý, zřídka doprovázený 2-5m mocnými endokontaktními načervenalými reakčními lemy. Hornina je nápadně páskovaná, jednotlivé pásky jsou orientovány paralelně s kontaktem. Většinou je zastoupen 1-200 cm pásek/zóna narůžovělého aplitu obsahující paralelní pásky euhedrálního granátu, rozpoznaného např. Staňkem (1981). V menší míře je pásek aplitu rozdělen paralelními hrubozrnnějšími pásky (Qtz, $\mathrm{Kfs}, \mathrm{Pl}) \mathrm{s}$ krystaly orientovanými kolmo na plochu pásku (obr. 2). Tyto hřebenovité krystaly tak splňují všechny předpoklady UST (Unidirectional Solidification Textures) struktur. Zřídka bývají některé žíly brekciovány fluoritovými žilami. Žilné granity jsou tvořeny xenomorfním křemenem (26-35 mod. \%), hypautomorfním zonálním plagioklasem (25-30 mod. \%) a hypautomorfním až automorfním draselným živcem (35-41 mod. \%). Jako vedlejší a akcesorické minerály jsou zastoupeny granát (1 mod. \%), biotit (0,5-5,0 mod. \%), magnetit, epidot, vzácně plumbopyrochlor, cheralit, titanit a zirkon. Granáty a K-živce vykazují oscilační a sektorovou zonálnost. Nejzajímavěǰí je vysoký obsah $\mathrm{Y}$, HREE $\left(2,80 \mathrm{hm}\right.$. \% $\left.\mathrm{Y}_{2} \mathrm{O}_{3}\right)$ v těchto granátech (Hönig et al. 2010). Vysoce frakcionované (nízké K/Rb 170-180, vysoké K/Ba 1034-2303, hluboká Eu anomálie) horniny suity typu Hlína mají subaluminický až slabě aluminický charakter (ASI 1,01), vnitrodeskovou (WPG) a postkolizní až anorogenní afinitu (Hönig et al. 2010, Leichmann a Novák 1999). 


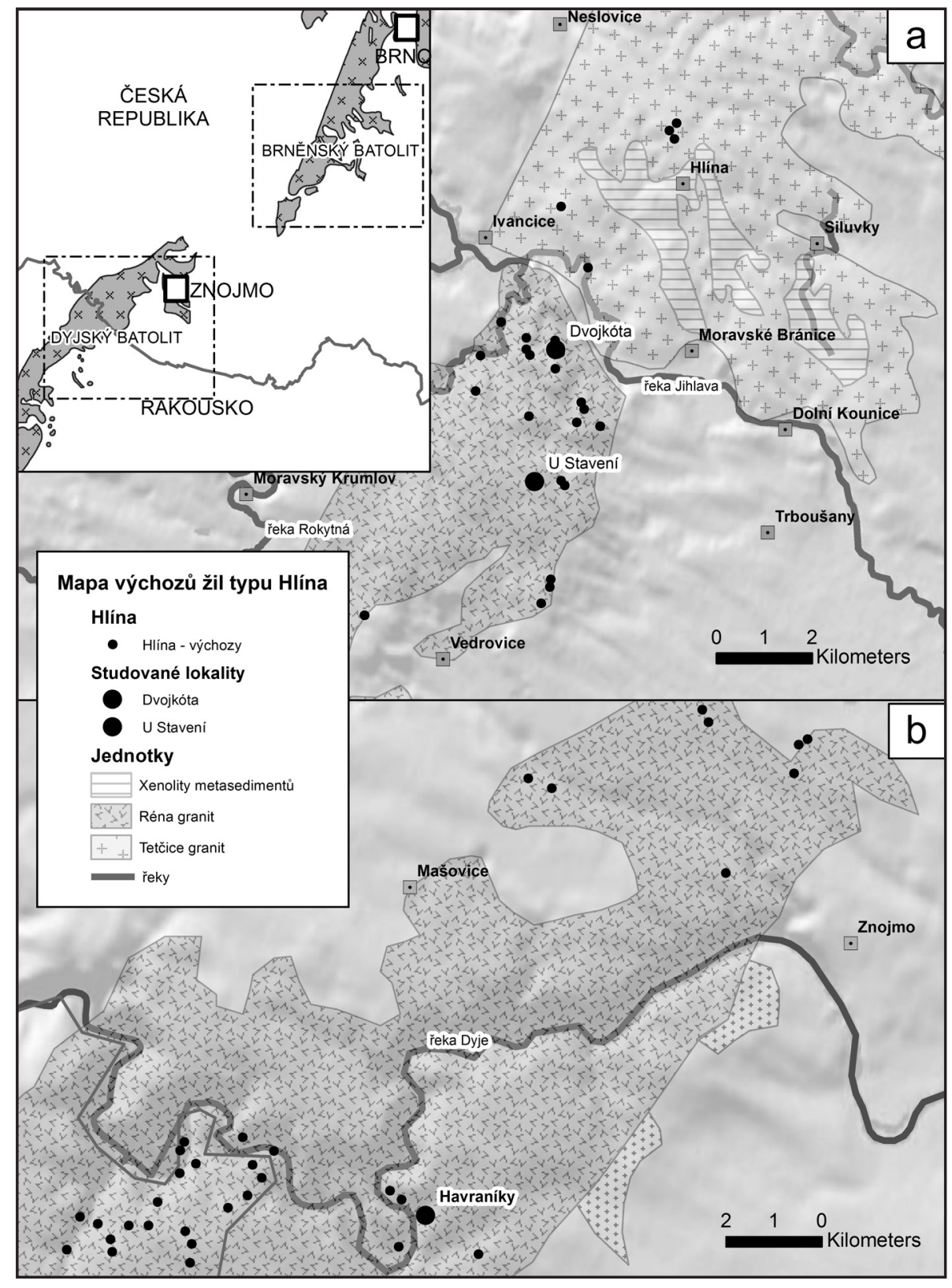

Obr. 1: Mapa plošného rozšíření žilných granitů suity typu Hlína v z. části brněnského batolitu (a) a s. části dyjského batolitu (b). Páskované granity se nejčastěji nachází uvnitř suity typu Réna, avšak drobné výskyty jsou známé i z granitů tetčické suity. Nejlepší studované výchozy jsou zvýrazněny a pojmenovány (viz Dvojkóta, U Stavení, Havraníky).

Fig. 1: Map shows occurrences of the layered granites of the Hlína layered suite inside the Brno batholith (a) and the Thaya batholith (b). Layered granites are widespread mostly inside the Réna suite granites, less commonly are observed inside the Tetčice suite.

\section{Dyjský batolit}

Podobnost mezi s. částí dyjského batolitu a j. částí batolitu brněnského konstatoval již Suess (1912). Obě tyto části byly také podrobně petrologicky srovnány i Fingerem et al. $(1995,2000)$. Leichmann a Höck (2008) přinesli př́imé srovnání jednotlivých typů granitů obou batolitů. Biotitické až amfibol-biotitické granity suity Réna odpovídají typu Pulkau/Zellendorf batolitu dyjského. Silně deformované granity tohoto typu vystupují rovněž i z. od Znojma a v nich byly nalezeny, podobně jako $v$ suitě Réna brněnského batolitu, studované žily páskovaných granátických granitů. Severovýchodní část dyjského batolitu, přibližně v. a sv. od Znojma, je tvořena jemnozrnnými biotitickými granodiority s četnými enklávami rul a dioritů, které Leichmann a Höck (2008) srovnávajís s granodiority suity Tetčice.

Horniny suity typu Hlína na území dyjského batolitu jsou velmi podobné žilným granitům pozorovaným $v$ granitech jz. části brněnského batolitu. Vyskytují se převážně v podobě drobných, max. $5 \mathrm{~m}$ mocných, žil nebo žilných rojů. Stejně jako $\mathrm{v}$ prrípadě brněnského batolitu, i zde se páskované granity objevují převážně $\mathrm{v}$ horninách typu Réna. Ve starších textech (Staněk 1987, Batík et al. 1990) jsou situovány převážně do oblasti sz. okraje granitů dyjského batolitu v okolí Tvořihráze, kde vystupují $\mathrm{v}$ zárezech cest. Nově byly páskované granity rozpoznány i v oblasti českého a rakouského pohraničí ve svazích údolí řeky Dyje z. od obce Havraníky. Údolí Dyje poskytuje svými př́krými, většinou nezakrytými svahy výborné podmínky pro mapování. Značné množství výchozů je také situováno na rakouské straně řeky, kde se páskované granity projevují spiše jako žilné roje a tělesa čočkovitého tvaru, dříve mapované rakouskou geologickou službou jako pegmatity s akcesorickým granátem (Roetzel et al. 2004). Podle geologické mapy národního parku Thayatal a Podyjí (1:25 000) tyto páskované granity nezasahují na rakouské území dále než cca $4 \mathrm{~km}$ j. od řeky Dyje. Tato informace ale nebyla $\mathrm{v}$ terénu nově prověřena. Protáhlý tvar žil není tak nápadný jako u žil brněnského batolitu. Kontakt s okolním granitem je většinou ostrý, nezřídka lemovaný krystaly křemene a živců rostoucími kolmo k ploše kontaktu žíly (připomínající orientované struktury stockscheideru). Žíly v některých prípadech sledují foliaci okolních granitů, většinou ji ale nerespektují a běžně jsou k ní kolmé (Batík 1983). Žilné granity typu Hlína jsou výrazně páskované, převažující zónou je většinou jemnozrnný aplit s laminovanou vnitřní strukturou. Pásky nebo zóny aplitu (většinou do $50 \mathrm{~cm}$ ) se opakovaně stř́dají $s$ méně mocnými $(1-10 \mathrm{~cm})$ pásky hřebenovitých UST 
krystalů Kfs, Qtz a podružně Pl. Ojediněle se objevují také paralelní pásky tmavé slídy, pravděpodobně biotitu. Granát je prítomen opět v podobě tenkých paralelních pásků, kde se jednotlivá euhedrální zrna navzájem dotýkají.

\section{Studované lokality}

Nejlépe odkryté lokality suity typu Hlína uvnitř brněnského batolitu nabízí lokalita pracovně nazývaná „Dvojkóta“ ležící v okolí kóty 334,6 m n. m. (WGS 1984

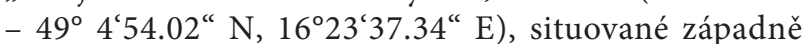
od obce Moravské Bránice a severně od kóty „U Stavení (415,4 m n. m.). Žíla zde tvoří výraznou elevaci protaženou cca $100 \mathrm{~m}$ ve směru SZ-JV. Horniny zde jsou výrazně páskované s majoritní aplitovou složkou. Pásky granátu přesahují několikametrovou délku. Druhou dobře odkrytou lokalitou jsou výchozy páskovaných granitů severně od hájenky U Stavení. Ta byla již dříve několikrát studována (Staněk 1981, Leichmann et al. 1999). Třetí zde prezentovanou lokalitou nabízející nejlepší výchoz těchto páskovaných granitů vůbec je lokalita označená Havraníky (WGS 1984 - 4849‘10.77 $\left.\mathrm{N}, 15^{\circ} 58^{`} 49.72^{\prime \prime} \mathrm{E}\right)$ nacházející se na levém břehu řeky Dyje v deformovaných granitech dyjského batolitu. Žilné granity zde tvoří žilné roje i samostatné žíly a žilky o maximální mocnosti $5 \mathrm{~m}$. Kolmo protínají foliaci okolních granitů. Nápadné je velmi transparentní a krásně vyvinuté vnitřní páskování. Výskyty jmenovaných lokalit jsou zobrazeny na obr. 1, fotografie páskovaných struktur na obr. 2.

\section{Akcesorický granát}

Y, HREE bohatý granát $\left(\mathrm{Sps}_{43-38}, \mathrm{Alm}_{35-24}\right.$, And $_{15-7}$, $\mathrm{Grs}_{21-15}, \operatorname{Prp}_{2-1}$ ) je v žilných granitech typu Hlína prrítomen značně nehomogenně. Vyskytuje se převážně v po době euhedrálních drobných $(\leq 1 \mathrm{~mm})$ zrn navzájem se dotýkajících, seřazených do drobných pásků nebo řetízků. Tyto paralelní řetízky se
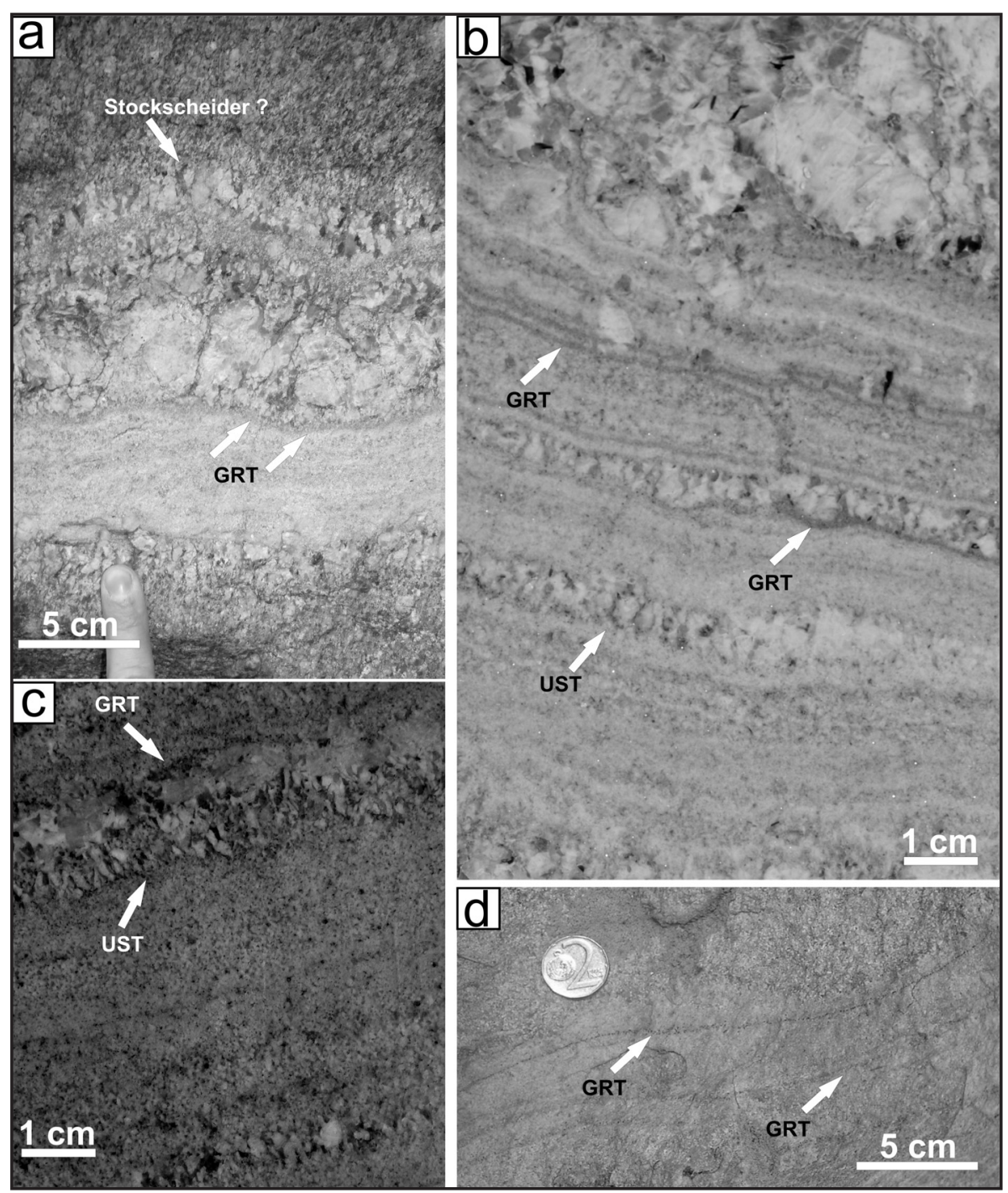

Obr. 2: Páskované granity brněnského batolitu (c, d) - UST hřebenovité krystaly Kfs, $\mathrm{Pl}$ a křemene orientované kolmo k páskování horniny střídající se s mocnými (až $2 \mathrm{~m}$ ) pásky/zónami jemnozrnného aplitu. Aplit obsahuje opakující se pásky granátu lemující hrubozrnnou UST polohu. Hornina je nápadně narůžovělá, zpravidla obsahující velké množství magnetitu asociujícího s granátem. Biotit je vzácný, vyskytující se jen na některých lokalitách. Páskované granity dyjského batolitu $(\mathrm{a}, \mathrm{b})$. Hornina nápadná výrazným páskováním UST krystalů křemene, Kfs a Pl. V některých částech žíla přechází do hrubozrnného pegmatitu. Granát seskupený do pásků lemujících UST zóny. Obsah granátu slábne směrem ke zmnožujícím se páskům biotitu.

Fig. 2: Layered granites of the Brno batholith (c, d) - UST comb-like crystals of Kfs, Pl and Qtz oriented perpendicularly to the rock lamination and alternating with up to $2 \mathrm{~m}$ thick zones of fine-grained aplite. Aplite contains stripes of garnet parallel to UST zones. Rock is pinkish, often content magnetite associated with garnet stripes. Biotite is rare and occurs only at several localities. Layered granites of the Thaya batholith $(\mathrm{a}, \mathrm{b})$. Rock is distinctive layered by UST consists of $\mathrm{Kfs}, \mathrm{Pl}$ and Qtz. In some cases the rock turns to coarse-grained, not oriented pegmatite. Garnet is also arranged into long stripes surrounding UST zones. Abundance of garnet gets weaker towards to biotite-rich bands or layers. 


\section{Shrnutí}

Páskované anorogenní vysoce frakcionované (ale subaluminické) žilné granity suity typu Hlína s NYF afinitou se relativně běžně vyskytují v granitech a granodioritech j. části brněnského batolitu a v s. části dyjského batolitu. Horniny tvoří většinou protáhlé žíly, popřípadě žilné roje. Kontakt s okolními granity je většinou ostrý. Žíly se zdají být nepostiženy variskou tektonizací, postihující okolní granity v dyjském batolitu. Na základě vymapovaných dat lze říci, že žilné granity typu Hlína jsou v terénu značně rozšířené (oblast výskytu překračuje 60 km v s.-j. směru) a jejich dosud známé lokality jsou limitovány pravděpodobně jen nedostatkem kvalitních výchozů. Páskované a UST struktury jsou považovány za produkt extrémně rychlé, kolem eutektika oscilující krystalizace volatiliemi chudé taveniny (viz Hönig et al. 2010). Pro další studium těchto žil je nezbytné přikročit $\mathrm{k}$ jejich datování a ověřit, př́padně vyvrátit jejich dřive předpokládané kadomské stárí.

\section{Poděkování}

Autoři dëkují recenzentům Karlu Breiterovi, PhD. a Doc. Rostovi Melicharovi, PhD. za podrobné pročtení textu a navrhnutí řšsení pro zlepšení čitelnosti manuskriptu. Publikovaná zpráva byla financována z projektu GAČR $P$ 210/10/1105. Autoři také děkují Davidu Buriánkovi, PhD. za věcné poznámky $k$ textu.

\section{Literatura}

Batík, P. - Čtyroký, P. (1983): Vysvětlivky k základní geologické mapě ČSSR, mapa 1: 25000 list Šatov 34-131. - Česká geologická služba Praha.

Finger, F. - Hanzl, P. - Pin, C. - Quadt, A. - Steyrer, H. P. (2000): The Brunovistulicum: Avalonian Precambrian at the eastern end of the Variscides. - In: Franke, W. - Altherr, R. - Haak, W. - Oncken, O. - Tanner, D. (eds): Orogenic processes: quantification and modelling in the Variscan Belt of Central Europe, Geological Society, London, Special Publications, $179,103-112$

Finger, F. - Frasl, G. - Dudek, A. - Jelínek, E. - Thoeni, M. (1995): Cadomian plutonism in the Moravo-Silesian basement. In: Dallmeyr, R. D. - Franke, W. - Weber, K. P. (eds): Tectonostratigraphic evolution of the central and eastern European orogens, Springer Verlag, Berlin, Heidlberg, New York, 495-507.

Hönig, S. (2008): Granátické granity a pegmatity brněnského masivu - nový typ UST v A-typových granitech? - MS, diplomová práce, PřF MU Brno.

Hönig, S. - Leichmann, J. - Novák, M. (2010): Unidirectional solidification textures and garnet layering in Y-enriched garnet-bearing aplite-pegmatites in the Cadomian Brno Batholith, Czech Republic. - Journal of Geoscience, 55, 81-97.

Leichmann, J. - Höck, V. (2008): The Brno Batholith: an insight into the magmatic and metamorphic evolution of the Cadomian Brunovistulian Unit, eastern margin of the Bohemian Massif. - Journal of Geoscience, 53, 218-305.

Leichmann, J. - Novák, M. - Sulovský, P. (1999): Peraluminous whole-rock chemistry versus peralkaline mineralogy of highly fractionated, garnet-bearing granites from the Brno Batholith. - Berichte der Deutschen Mineralogischen Gesellschaft. Beihefte zum European Journal of Mineralogy 1, 144

Novosád, T. (2011): Gamaspektrometrická charakteristika žilných granátických granitů jižní části brněnského masivu. - MS, bakalařská práce, PřF MU Brno.

Roetzel, R. - Fuchs, G. - Batík, P. - Čtyroký, P. - Havlíček, P. (2004): Geologische karte der nationalparks Thayatal und Podyjí. Karte $1: 25$ 000. - Geologische Bundesanstalt, Wien.

Staněk, J. (1981): Akcesorické minerály světlých žilných hornin brněnského masivu. - Folia Facultatis scientiarum naturalium Universitatis Masarykianae Brunensis, Geol., 22, 3, 55-58.

Staněk, J. (1982): Minerals of the Brno Massif. - In: Štelcl, J. (ed.): Sborník příspěvků konference Brno a geologie, Brno, 182-185. Staněk, J. (1987): Garnets from granitoid and pegmatitoid rocks of the Dyje massif. - Scripta facultatis scientiarum naturalium Universitatis Purkynianae Brunensis Geology, 17, 1, 21-28.

Suess, F. E. (1912): Die Moravischen Fenster und ihre Beziehung zum Grundgebirge des Hohen Gesenke. - Denkschriften der österreichischen Kaiserlichen Akademie der Wissenschaften, mathematisch-naturwissenschaftliche, 1-91. 